\title{
Design and Optimization of PHC Pipe Pile in Binzhou Port
}

\author{
Xiaowen Bian', Xiaoli Ren, Zhaojun Ren \\ Department of Architectural Engineering, Binzhou Polytechnic, Binzhou, 256603, China \\ a'E-mail: 179042508@qq.com
}

Keywords: Binzhou port; The frame-fixed row-pattern pile cofferdam structure; The PHC pipe pile; Design optimization

\begin{abstract}
The problems of the frame-fixed row-pattern pile cofferdam structure construction are analyzed based on the correlative situation of cofferdam in Haigang district of Binzhou port for liquid bulk cargo operation. According to the problem, two schemes to optimize the frame-fixed row-pattern pile cofferdam structure are proposed. After the calculation and analysis of the bearing capacity of PHC pile, the scheme of changing pile diameter or pile length is proposed. The two schemes are compared economically and the optimal scheme is determined, in the hope that this scheme can be used as a reference for later construction.
\end{abstract}

\section{Introduction}

Binzhou port is located in the north of shandong province, binzhou area wudi and zhanhua county at the junction of the tao er estuary. Port plays a very important role in the whole integrated transportation system and promotes the development of regional economy. But the port is a capital intensive industry, one-time investment is huge. phase I project construction investment of Binzhou port haigang district reached 6.3 billion yuan. So how to save investment and reasonable construction of port is very important. According to the experience of project cost management, the decision-making and design stage is the most important stage to control the project cost. The rationality of design and convenience of construction are the key factors that can save project cost. But many design problems occur or are discovered in practice. We must revise and perfect it in time according to the problems, so as to provide the basis for the later construction decision and design of binzhou port.

\section{Project summary}

The construction of Cofferdam for the liquid bulk cargo area of Binzhou port is located in the liquid bulk operation area planned by Binzhou port, and 30 thousand tons of wharf have been built near the port area. This project adopts a new type of hydraulic structure -- he frame-fixed row-pattern pile cofferdam structure. The structure is similar to the plate-pile structure in force, and combines the advantages of high-pile structure and gravity structure. In terms of construction, it draws lessons from the successful experience of plug-in box barrel and lattice steel sheet pile. It is an upright structure with high construction speed, low material consumption and low project cost. the frame-fixed row-pattern pile cofferdam structure is composed of integral frame structure, PHC pipe pile, cap beam, retaining wall, etc. The most innovative point of the structure is to install the frame before piling. The frame is not only the ring beam to ensure the uniform stress of the front and rear wall piles, but also the tie rod connecting the two rows of wall piles, and also the limit guide frame for pile construction. The frame is composed of guide beam, column, connecting beam and baffle. Pile holes is reserved on the guide beam. Pile hole can play a guiding and limiting role in pile construction. The structural composition diagram is shown in figure 1: 


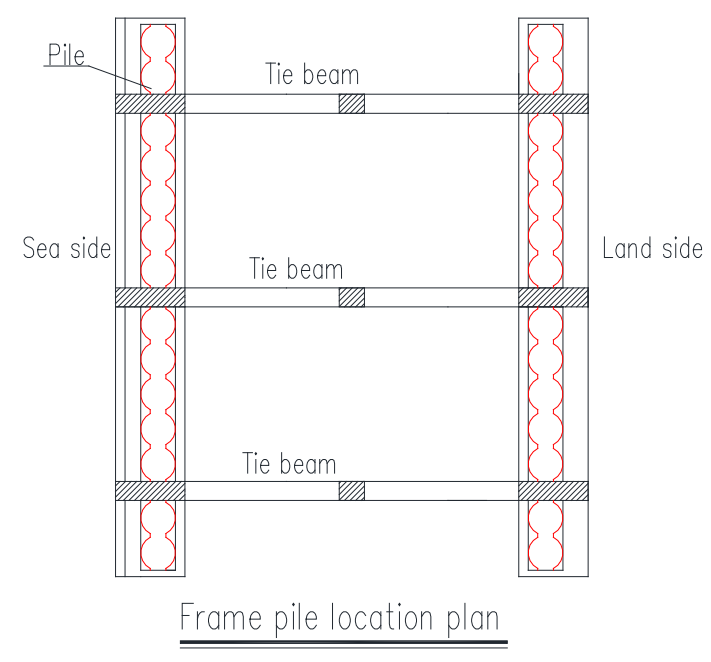

Figure 1 Frame-fixed row-pattern pile cofferdam structure

The wall pile frame structure can make up many shortcomings of the traditional slope type cofferdam. The traditional slope type cofferdam requires a large amount of sand. It requires Large structural section and large area occupied by the sea. It is difficult to be connected with the wharf construction in the later stage. As road subgrade, it uneven settlement is easy to occur. There are many social vessels, which are prone to safety accidents.

\section{Problems existing in the construction of frame-fixed row-pattern pile cofferdam structure}

The construction of frame-fixed row-pattern pile cofferdam structure adopted by the PHC Pressurized concrete pipe pile in the cofferdam of liquid bulk cargo operation area of Binzhou Port adopts hammering piling technology. The PHC prestressed concrete pipe pile adopts the square barge crane unit to lift and hit the hydraulic hammer for construction.PHC prestressed concrete pipe pile adopts PHC prestressed concrete pipe pile. After The installation of the frame, positioning piles are firstly set up. Four positioning piles are set up for each frame. After the reinforcement is completed, the remaining pipe piles shall be driven , and 28 piles shall be built for each frame. In order to improve the efficiency of piling,2 260t crawler cranes mounted on a square barge are responsible for pile insertion. Another 260t square barge crane unit is arranged to be responsible for piling, inserting and piling water construction. The PHC prestressed concrete pipe running the first short for tensioning prestressed concrete pipe pile, diameter of $\Phi 800 \sim \Phi 1400 \mathrm{~mm}$ is widely used in port engineering, it has high strength, permeability resistance ability, The characteristics of high bearing capacity, hammer resistance is strong, widely applied in the small and medium-sized port. PHC pile, with a diameter of $1000 \mathrm{~mm}$ and a wall thickness of $130 \mathrm{~mm}$, is adopted for the wall pile frame structure of this project. The pipe pile prefabrication is carried out by dalian prefabrication factory. The parameters of the PHC prestressed concrete pipe pile are as follows:

Table 1 parameters of PHC pile of wall pile frame structure

\begin{tabular}{l|l|l|l|l|l}
\hline Pile No. & $\begin{array}{l}\text { Diameter } \\
(\mathrm{mm})\end{array}$ & $\begin{array}{l}\text { Effective pile } \\
\text { length(m) }\end{array}$ & $\begin{array}{l}\text { Enter the holding } \\
\text { depth } \\
(\mathrm{m})\end{array}$ & $\begin{array}{l}\text { Pile bottom } \\
\text { elevation } \\
(\mathrm{m})\end{array}$ & quantity(root) \\
\hline $1000-130-\mathrm{C}$ & 1000 & 23 & 1.0 & -20 & 1932 \\
\hline
\end{tabular}

Hydraulic impact hammer with force source hhp-16 and hhp-20 hammer core can meet the requirements of pile driving construction. Due to geological data, pile type and pile length estimation. As the diameter of the reserved pile hole on the frame is $1100 \mathrm{~mm}$, and the diameter of the pipe pile is $1000 \mathrm{~mm}$, there is a gap of $100 \mathrm{~mm}$. After the pipe pile is inserted into the pile hole, there will be a certain inclination.It will not only affect the construction of adjacent pipe piles, but 
also generate additional bending moment due to eccentric force when piling, and even cause pile breaking accident in serious cases. In order to ensure that the verticality of piles meets the requirements in the construction process, the piling guide frame is used to assist the construction. Pile driving guide frame is welded by channel steel and I-beam steel. It is $2.5 \mathrm{~m}$ high and weighs about 8t. It has movable back plate on top and four groups of top wheels on back plate.By adjusting the position of the top wheel with top screw and bolt, the position of the pipe pile is limited to ensure that the vertical degree of the pile in the process of piling meets the requirements of the code and design..

However, it was found in the construction process that although a series of measures were taken, the pile sinking process was limited due to the small spacing between piles, which greatly affected the construction speed. In addition, during the construction process, the perpendicularity of the pile is not easy to control. Even if the perpendicularity of the previous pile is within the allowable range, it will affect the construction of the next pile. Based on this problem found in the construction, the PHC prestressed concrete pipe pile was designed and optimized.

\section{Engineering geological condition}

According to the geological survey data (July 2013), the elevation of the original mud surface in the project construction area is $-2 m \sim-5 m$, and the deep grooves of the mud is $-9 m \sim 11 m$. The soil layer above the elevation of $-15 \mathrm{~m}$ is generally silt and silty clay, and the soil layer below $-15 \mathrm{~m}$ is silty clay, silty sand and clay. The geological conditions of the site are shown in table 2 .

Table 2 The soil physical and mechanical properties index table

\begin{tabular}{|c|c|c|c|c|c|c|c|}
\hline $\begin{array}{l}\text { Soil } \\
\text { layer } \\
\text { no. }\end{array}$ & $\begin{array}{l}\text { Soil } \\
\text { name }\end{array}$ & $\begin{array}{l}\text { Soil } \\
\text { thickness } \\
\text { (m) }\end{array}$ & $\begin{array}{l}\text { Bottom } \\
\text { elevation( } \\
\text { m) }\end{array}$ & $\begin{array}{l}\text { Cohesive } \\
\text { force } \\
\mathrm{c}(\mathrm{kPa})\end{array}$ & $\begin{array}{l}\text { Internal } \\
\text { friction } \\
\text { Angle } \Phi\left(^{\circ}\right)\end{array}$ & $\begin{array}{l}\text { Specific } \\
\text { penetration } \\
\text { resistance } \\
\text { PS(MPa) }\end{array}$ & $\begin{array}{l}\text { Standard } \\
\text { penetration } \\
\text { N63.5(hit) }\end{array}$ \\
\hline (1) 1 & Silt & $0.2 \sim 2.0$ & & & & & \\
\hline (1) 2 & $\begin{array}{l}\text { silty } \\
\text { clay }\end{array}$ & $1.0 \sim 7.7$ & & 6.7 & 2.2 & & $<1$ \\
\hline (1) 3 & $\begin{array}{l}\text { Silty } \\
\text { clay }\end{array}$ & $1.0 \sim 10.9$ & & 12 & 1.16 & & $<1$ \\
\hline (1) 6 & Clay & $1.0 \sim 5.0$ & & & & & 3.4 \\
\hline (1) 7 & Silt & $0.7 \sim 5.0$ & & & & & 13.3 \\
\hline (2) & $\begin{array}{l}\text { Silty } \\
\text { sand }\end{array}$ & $0.6 \sim 11.9$ & & & & & 41.3 \\
\hline (2) 1 & Silt & $1.1 \sim 6.0$ & & & & & 28.7 \\
\hline (2) 2 & $\begin{array}{l}\text { Silty } \\
\text { clay }\end{array}$ & $1.1 \sim 4.7$ & & & & & 14.5 \\
\hline (2) 3 & Clay & $0.7 \sim 5.0$ & & 27 & 2.1 & & 8.3 \\
\hline (2) 4 & Silt & 1.0 & & 11.0 & 7.1 & & 16.8 \\
\hline (3) 1 & $\begin{array}{l}\text { Silty } \\
\text { clay }\end{array}$ & $1.8 \sim 5.7$ & & & & & 12 \\
\hline (3) 2 & Clay & 5.3 & & 28 & 4.0 & & 10.6 \\
\hline (3) 3 & Silt & 3.3 & & & & & 37.9 \\
\hline (4) 2 & Silt & $4.8 \sim 5.7$ & & & & & 39.9 \\
\hline
\end{tabular}

5. Design optimization of the Frame-fixed Row-pattern Pile Cofferdam

\subsection{Determination of holding layer of PHC pile}

According to the geological survey report, PHC pile selects silty sand layer in medium density 
state and clay layer in plastic state as holding layer, In order to ensure the pile bearing capacity to meet the design requirements, and the depth of pile tip entering the bearing layer shall not be less than $1.0 \mathrm{~m}$. Design parameters of single pile capacity are given in table 3:

Table 3 PHC pile side resistance and pile end resistance eigenvalue list

\begin{tabular}{|c|c|c|c|c|c|}
\hline $\begin{array}{c}\text { Soil } \\
\text { layer } \\
\text { no. }\end{array}$ & $\begin{array}{c}\text { Soil } \\
\text { name }\end{array}$ & $\begin{array}{c}\text { Average } \\
\text { thickness (m) }\end{array}$ & $\begin{array}{c}\text { Pile side } \\
\text { resistance } \\
\text { characteristic } \\
\text { value } q_{s i a}\end{array}$ & $\begin{array}{l}\text { Pile-end } \\
\text { resistance } \\
\text { value } \\
\text { features } \\
q_{p a /} \\
\end{array}$ & $\begin{array}{c}\text { Standard } \\
\text { penetration } \\
\mathrm{N} \text { ( hit ) }\end{array}$ \\
\hline 1 & Silt & 3.54 & 15 & & \\
\hline 1-夹 1 & $\begin{array}{l}\text { Silty } \\
\text { clay }\end{array}$ & 1.66 & 26 & & \\
\hline 1-夹 2 & Silt & 3.55 & 25 & & \\
\hline $1-2$ & $\begin{array}{l}\text { Silty } \\
\text { clay }\end{array}$ & 2.95 & 10 & & \\
\hline $1-3$ & $\begin{array}{l}\text { Silty } \\
\text { clay }\end{array}$ & 3.65 & 18 & & \\
\hline $1-4$ & $\begin{array}{l}\text { Silty } \\
\text { clay }\end{array}$ & 3.6 & 31 & & 5.5 \\
\hline $2-1$ & Silt & 4 & 60 & 2000 & 24.2 \\
\hline $2-2$ & Silt & 6.3 & 50 & 2300 & \\
\hline 3 & $\begin{array}{l}\text { Silty } \\
\text { clay }\end{array}$ & 5.83 & 45 & 1400 & 16.2 \\
\hline 3-夹 & $\begin{array}{l}\text { Silty } \\
\text { clay }\end{array}$ & & 18 & & \\
\hline 4 & Clay & 6.54 & 40 & & 7.8 \\
\hline $5-1$ & $\begin{array}{l}\text { Silty } \\
\text { clay }\end{array}$ & 2.06 & 70 & 2200 & 13 \\
\hline $5-2$ & Silt & 2.68 & 62 & 3600 & 26.3 \\
\hline $5-3$ & $\begin{array}{l}\text { Silty } \\
\text { clay }\end{array}$ & 2.2 & 65 & 2500 & 13 \\
\hline
\end{tabular}

\subsection{Determine the characteristic value of Single-pile vertical endurance}

The characteristic value of Single-pile vertical endurance is estimated by using equation 4.2.4-1 in JTS 167-4-2012 《Code for pile foundation of port engineering》, The calculation process is as follows:

$$
\mathrm{Q}_{\mathrm{d}}=\frac{1}{\gamma_{\mathrm{R}}}\left(\mathrm{U} \Sigma \mathrm{q}_{\mathrm{fi}} \mathrm{l}_{\mathrm{i}}+\mathrm{q}_{\mathrm{R}} \mathrm{A}\right)
$$

In the formula, $Q_{d}$ is the characteristic value of Single-pile vertical endurance $(K N) ; \gamma_{R}$ is the component coefficient of vertical bearing capacity of single pile; $U$ is the girth of pile section; $q_{\mathrm{f}}$ is the standard value of ultimate lateral friction resistance per unit area of single pile layer I soil $(\mathrm{kPa}) ; \mathrm{l}_{\mathrm{i}}$ is the length of the pile through the ith layer of $\operatorname{soil}(\mathrm{m}) ; \mathrm{q}_{\mathrm{R}}$ is the standard value of ultimate pile tip resistance per unit area of a single pile $(\mathrm{kPa})$;A is the section area of pile body $\left(\mathrm{m}^{2}\right)$.

So, there are two kinds of optimizations based on the path and the length of the pile:Plan 1,he pile diameter changed from $1000 \mathrm{~mm}$ to $800 \mathrm{~mm}$, In order to ensure the bearing capacity of the pile, the effective pile length is increased from the original design of $23 \mathrm{~m}$ to $30 \mathrm{~m}$.Plan 2,The pile diameter remains unchanged at $1000 \mathrm{~mm}$, and the pile end bearing layer extends from 2-2 layers of silty soil to 5-2 layers of silty sand. The effective pile length is $42 \mathrm{~m}$.

Take the column diagram of a borehole in 《Geotechnical engineering survey report》 as an 
example,and the calculation results of bearing capacity are shown in table 4 .

Table 4 The result of characteristic value estimation of vertical bearing capacity of single pile

\begin{tabular}{|c|c|c|c|c|}
\hline $\begin{array}{c}\text { Pile } \\
\text { diameter } \\
(\mathrm{mm})\end{array}$ & $\begin{array}{c}\text { Effective } \\
\text { pile length } \\
(\mathrm{m})\end{array}$ & $\begin{array}{c}\text { Enter the } \\
\text { holding } \\
\text { depth }(\mathrm{m})\end{array}$ & $\begin{array}{c}\text { Pile bottom } \\
\text { elevation }(\mathrm{m})\end{array}$ & $\begin{array}{c}\text { the characteristic value } \\
\text { of Single-pile vertical } \\
\text { endurance }(\mathrm{kN})\end{array}$ \\
\hline 800 & 30 & 3.0 & -27 & 2346 \\
\hline 1000 & 23 & 1.0 & -20 & 2310 \\
\hline 1000 & 42 & 1.0 & -39 & 4901 \\
\hline
\end{tabular}

\section{The frame-fixed row-pattern pile cofferdam structure was compared and optimized}

According to the two optimization design schemes of PHC pile with the frame-fixed row-pattern pile cofferdam structure, the reinforcement is shown in figure 2 and figure 3 :

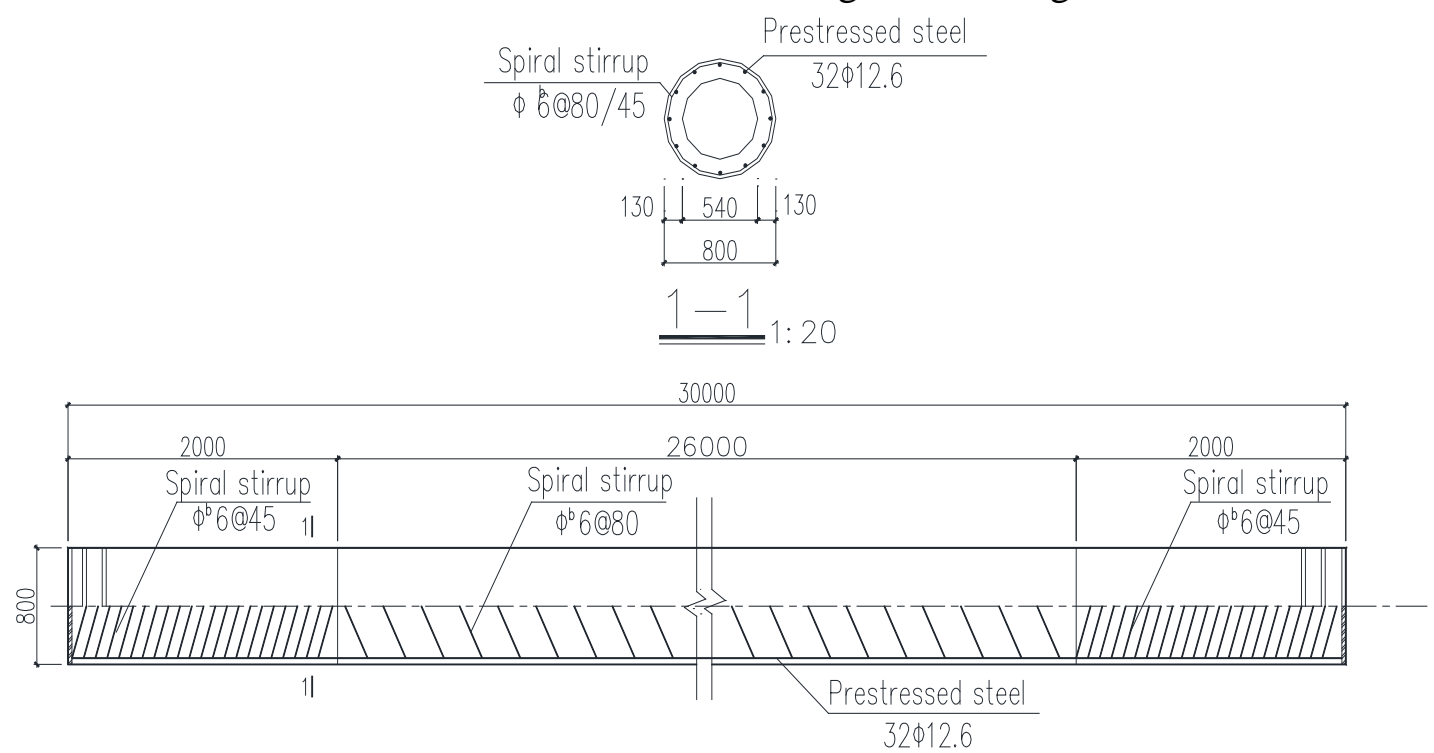

Figure 2 reinforcement of the PHC800-C-130-30
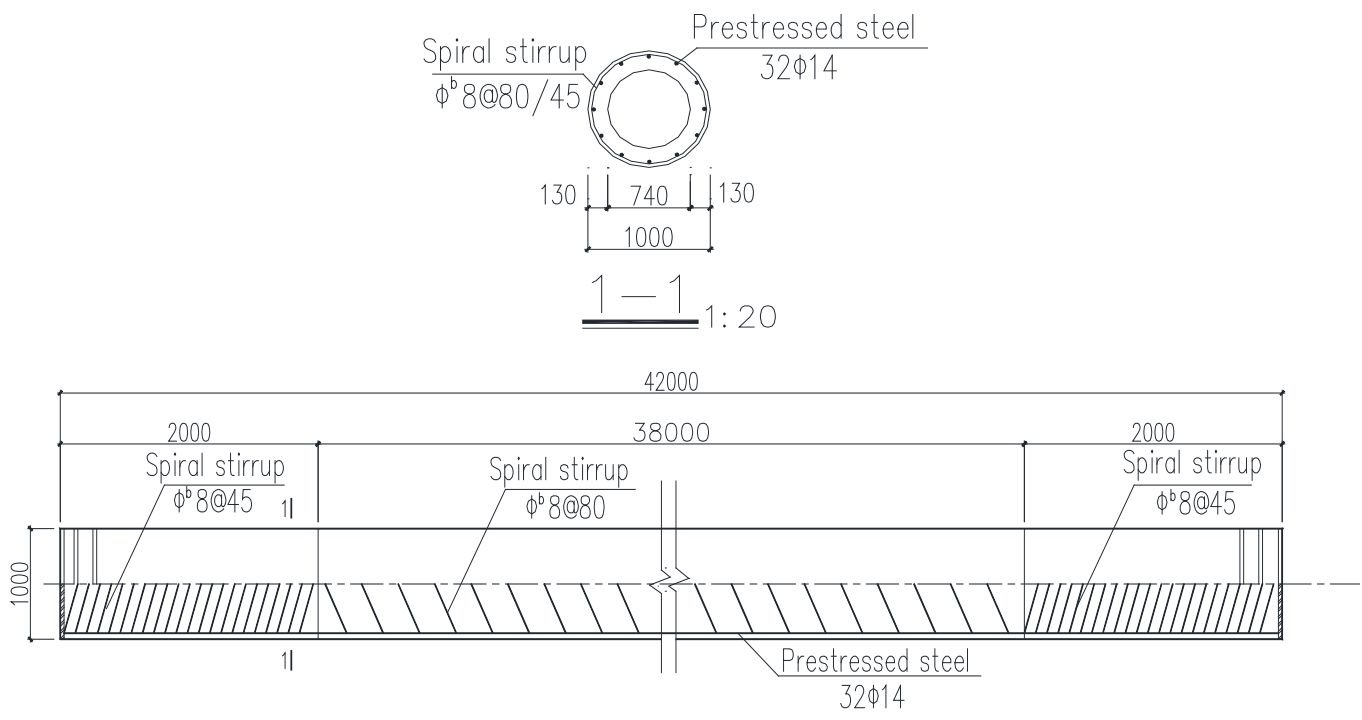

Figure 3 Reinforcement of the PHC1000-C-130-42

According to the requirements of the specification, the project cost of scheme 1 and scheme 2 is calculated as shown in table 5: 
Table 5 Project cost

\begin{tabular}{|c|c|c|c|c|c|}
\hline $\begin{array}{l}\text { Design } \\
\text { scheme }\end{array}$ & Pile model & $\begin{array}{l}\text { Steel } \\
\text { dosage(kg) }\end{array}$ & $\begin{array}{l}\text { Concrete } \\
\text { content(M3) }\end{array}$ & Number & $\begin{array}{l}\text { Project } \\
\text { cost(yuan) }\end{array}$ \\
\hline scheme 1 & $\begin{array}{l}\text { PHC800-C-13 } \\
0-30\end{array}$ & 1114.4 & 24 & 1932 & 2876554.8 \\
\hline scheme 2 & $\begin{array}{l}\text { PHC1000-C-1 } \\
30-42\end{array}$ & 2151.74 & 42 & 966 & 2013588.36 \\
\hline
\end{tabular}

As can be seen from the above table, the project cost of phc1000-c-130-42 pile of plan 2 is lower than that of phc800-c-130-30 pile of plan 1. Economically, the PHC1000-C-130-42 pile is superior to the PHC800-C-130-30 pile.

\section{Conclusion}

The construction investment of Binzhou Port is huge, so how to save investment and build a port rationally is a very important issue. The frame-fixed row-pattern pile cofferdam structure is a new type of structure, so the problems existing in the design can only be found out and solved in time in the construction practice. Based on the problems existing in the construction of the frame-fixed row-pattern pile cofferdam structure and based on the actual geological conditions of Binzhou port, this paper proposes two design optimization schemes, which are mainly aimed at changing the diameter and length of the frame-fixed row-pattern pile cofferdam structure PHC pile, in order to increase the construction surface between piles.

\section{Acknowledgements}

Study on the application of the frame-fixed row-pattern pile cofferdam structure- a case study of binzhou port (J15LG55)

\section{References}

[1] Bart W. Wiegmans, Erik Louw. Changing port-city relations at Amsterdam. A newphase at the interface. Journal of Transport Geography, 2011, 19:579-583

[2] Yao Haiyuan. Research on the structure of wall-pile frame wharf [D]. Tianjin: Tianjin University, 2013.

[3] Qiu Lu. Study on Investment Risk Assessment of Binzhou Port Liquid Chemical Terminal [D]. Shandong: China Ocean University, 2014

[4] Li Jingpei, Yue Zhuwen, et al. Design Life Calculation of PHC Pipe Piles in Marine Environment [J]. Journal of Silicate, 2014 (4).

[5] Huang Runqiu, Xiang Xiqiong. Evaluation of Port Environmental Carrying Capacity Based on Fuzzy Matter Element Analysis [D]. Liaoning: Dalian Maritime University, 2014. 